\title{
Article \\ Effect of Different Temperature Regimes on the Germination of Pseudolysimachion pusanensis (Y. N. Lee) Y. N. Lee Seeds
}

\author{
Mi-Hyun Lee, Jin-Hyun Lim, Cho-Hee Park, Jun-Hyeok Kim and Chae-Sun Na *D \\ Baekdudaegan National Arboretum, Bonghwa-gun 36209, Korea; hyun3176@koagi.or.kr (M.-H.L.); \\ jhim04@koagi.or.kr (J.-H.L.); epurerbeau@koagi.or.kr (C.-H.P.); kjh9859@koagi.or.kr (J.-H.K.) \\ * Correspondence: chaesun.na@koagi.or.kr; Tel.: +82-054-679-2769
}

Citation: Lee, M.-H.; Lim, J.-H.; Park, C.-H.; Kim, J.-H.; Na, C.-S. Effect of Different Temperature Regimes on the Germination of Pseudolysimachion pusanensis (Y. N. Lee) Y. N. Lee Seeds. Horticulturae 2021, 7, 577. https:// doi.org/10.3390/horticulturae7120577

Academic Editor: Sergio

Ruffo Roberto

Received: 5 November 2021

Accepted: 8 December 2021

Published: 14 December 2021

Publisher's Note: MDPI stays neutral with regard to jurisdictional claims in published maps and institutional affiliations.

Copyright: () 2021 by the authors. Licensee MDPI, Basel, Switzerland. This article is an open access article distributed under the terms and conditions of the Creative Commons Attribution (CC BY) license (https:// creativecommons.org/licenses/by/ $4.0 /)$.

\begin{abstract}
In this study, we determined the germination response in the seeds of the rare plant Pseudolysimachion pusanensis (Y. N. Lee) Y. N. Lee to different temperatures. P. pusanensis seeds were collected from the Baekdudaegan National Arboretum, South Korea, in November 2019, and dried. Dry seeds were placed at constant and alternating temperatures $\left(5^{\circ} \mathrm{C}, 10^{\circ} \mathrm{C}, 15^{\circ} \mathrm{C}, 20^{\circ} \mathrm{C}\right.$, $25^{\circ} \mathrm{C}, 30^{\circ} \mathrm{C}$, and $35^{\circ} \mathrm{C}$ ) to determine their germination percentage (GP). The seeds were exposed to 59 temperature combinations ranging from $5{ }^{\circ} \mathrm{C}$ to $43{ }^{\circ} \mathrm{C}$ using a thermal gradient plate. The photoperiod was set at 12:12 $\mathrm{h}$ (light:dark) and germination assays were performed five times a week. Subsequently, the seed GP and the number of days required to reach $50 \%$ of the germination $\left(\mathrm{T}_{50}\right)$ were determined. The highest final GP was $94.38 \%$, with a $\mathrm{T}_{50}$ value of $9.26 \mathrm{~d}$ at $15{ }^{\circ} \mathrm{C}$. However, the mean germination time was $12.5 \mathrm{~d}$ at $15^{\circ} \mathrm{C}$, and linear regression using $1 / \mathrm{T}_{50}$ revealed that the base temperature ranged from $2.69{ }^{\circ} \mathrm{C}$ to $4.68{ }^{\circ} \mathrm{C}$. These results for P. pusanensis seeds stored in a seed bank provide useful data for the native plants horticulture industry and can also be utilized for storage management.
\end{abstract}

Keywords: seed germination; thermal gradient plate; seedbank; Pseudolysimachion pusanensis; base temperature; storage management

\section{Introduction}

Species in the genus Veronica represent a large group of annual or perennial herbs [1] that are distributed across Eurasia in the northern hemisphere through to the southern hemisphere (Australia, New Zealand, New Guinea) [2,3]. The Veronica subgenus Pseudolysimachium comprises approximately 450 species and is used for ornamental horticulture in gardening, including V. spicata and V. longifolia [4,5]. This subgenus is particularly popular in horticulture because the flowers bloom from spring to autumn, resulting in a long flowering period. Moreover, these species are easy to manage when planted in a garden. In addition, this subgenus has gained attention in recent years due to the ease of hybridization, and the addition of various flower colors and new cultivars [6].

Veronica pusanensis Y. N. Lee [7] was first identified in Gijang-gun, Busan, Republic of Korea, and exhibits several morphological differences compared to other species of the genus. Therefore, Y. N. Lee renamed V. pusanensis as Pseudolysimachion pusanensis (Y. 'N. Lee). Y. N. Lee [8]. P. pusanensis is a rare plant that is classified as data-deficient [9] and is distributed only in Busan [10]. P. pusanensis is characterized by purple racemes and is of dwarf type, and grows by crawling along the ground. To maintain P. pusanensis horticulturally with different traits and to conserve the genetic resources of this rare plant, it is important to investigate its optimal conditions for growth.

In Korea, basic growth research has been carried out for enhancing the development of new ornamental plants and cultivating excellent varieties of 20 plant species in the genus Veronica [11] in order to understand the flowering and light conditions of the genus [12], along with plant propagation research through stem cutting using various 
types of auxins [13]. Although this research is actively conducted to secure the breeding material of native genera, the primary method to protect and preserve original species remains seed storage. Internationally, seeds are stored in seed vaults and seed banks. In 2008, the Svalbard Global Seed Vault in the frozen Norwegian island of Spitsbergen was commissioned for the storage of crop seeds, and the Baekdudaegan Global Seed Vault (BGSV) was instituted at the Baekdudaegan National Arboretum to store the seeds of wild plants [14]. Seed bank collections of wild species contribute to habitat restoration and species reintroductions [15-17]. Therefore, further investigations on seed germination and seedling growth are necessary to effectively use the seeds of wild species and maintain the processes in seed banks.

Additionally, wild plant seeds show different types of dormancy and dormancy depths [18]. Dormancy is a crucial plant trait to prevent germination during unfavorable conditions, and serves as insurance for seed survival $[19,20]$. Among the genus Veronica, $V$. parnkalliana seeds show morphophysiological dormancy (MPD) due to undeveloped embryos and the inhibition of the physiological mechanism in the embryo $[18,21]$, and $V$. kiusiana seeds show non-deep simple MPD according to the physiological dormancy depth [10]. Conversely, V. pusanensis, V.'dahurica, V. rotunda, V. nakaiana, V. pyrethrina, and $V$. kiusiana show morphological dormancy (MD) due to undeveloped embryos [10].

The base temperature refers to the basic temperature requirements of herbaceous species for seed germination and emergence. The estimation of the base temperature can help to predict seed germination and determine the suitable sowing time based on the local temperature [22]. Germination processes are regulated by the accumulated temperature above the base temperature [23]. Further, the seed germination index indicates the dynamics of the germination process, allowing for a comparison of species with similar germination [24].

With the aim of contributing to the horticulture industry using native plants, in this study, we investigated the most basic morphology of P. pusanensis seeds and further estimated the base temperature, according to the germination index, for the germination of dry P. pusanensis seeds.

\section{Materials and Methods}

\subsection{Material Collection and Seed Processing}

P. pusanensis seeds were collected from the exhibition garden of the Baekdudaegan National Arboretum (Bonghwa-gun, $37^{\circ} 00^{\prime} 31.3^{\prime \prime} \mathrm{N} 128^{\circ} 49^{\prime} 49.0^{\prime \prime} \mathrm{E}$ ). In Bonghwa-gun, the average annual temperature ranges from $-3{ }^{\circ} \mathrm{C}$ to $22.5^{\circ} \mathrm{C}$ and the annual rainfall is $>1229 \mathrm{~mm}$.

P. pusanensis plants exhibit indeterminate inflorescence; therefore, they produce differentially matured seeds. The basal flowers of the inflorescence used in this study bloomed at the end of August, whereas the uppermost flowers bloomed in mid-October. Plants, with seeds just before their release from the inflorescence, and free from insects, were collected on 20 November 2019. Subsequently, they were dried under the tree canopy, and then were passed through various sieves and winnowed to extricate the filled seeds. Filled seeds were then dried in a drying room [temperature: $15^{\circ} \mathrm{C}$; relative humidity $(\mathrm{RH}): 15 \%$ ] and sealed in aluminum packages for storage in a short-term storage room (temperature: $4{ }^{\circ} \mathrm{C}$; RH: 15\%) in December 2019 until further experiments. During the experiments, the seeds were stored with silica gel over the short term.

\subsection{Seed Morphology}

Ten seeds and a seedling were photographed using a digital microscope (Leica Microsystems DVM6-Leica PlanApo; Leica, Wetzlar, Germany) to determine their morphology. Seed size was measured from digital images captured using the DVM6 microscope equipped with the Leica Application Suite X (LAS X) software. Seed images were captured, and the seed length, width, and cross-sectional area, along with the length of the embryo at dispersal and just before germination, were measured using the digital microscope and 
associated software. Subsequently, embryo:seed (E:S) ratios at seed dispersal and just before germination were assessed using paired $t$-tests.

\subsection{Estimation of 1000-Seed Weight}

Ten replicates with 100 seeds were weighed and used to calculate the mean 1000-seed weight.

\subsection{Estimation of Initial Seed Moisture Content (MC)}

Seed MC (\%, fresh-weight basis) was determined before storage in sealed containers at the Baekdudaegan seed bank. In the drying room, seeds were equilibrated for 1-2 weeks to reach the equilibrium point ( $\mathrm{RH}: 15 \%$ ) to measure their equilibrium relative humidity (ERH) using a Rotronic hygrometer (HC2-AW; Rotronic Instruments UK Ltd., Crawley, UK) connected to HW4-E software V3.9.0 [25]. Seed MC was then determined using the lowtemperature oven drying method, as detailed by the International Seed Testing Association (ISTA) [26].

Briefly, samples were ground and placed on aluminum foil dishes, with each ground seed weighing $1 \mathrm{~g}$. Seeds were dried at $103 \pm 2{ }^{\circ} \mathrm{C}$ for $17 \pm 1 \mathrm{~h}$ [26] and cooled in a desiccator. After cooling, seeds were weighed to determine weight loss. All samples were assessed in quadruplicates.

Seed MC was calculated using the following formula and expressed as a percentage of the fresh seed weight:

$$
\mathrm{MC}=[(\text { weight } \text { of fresh seeds }- \text { weight of dried seeds }) / \text { weight of fresh seeds }] \times 100
$$

\subsection{Estimation of Total Protein Content}

Seeds were ground and their protein content was determined via the standard Kjeldahl method [27] using a Kjeltec analyzer (Kjeltec 8400; FOSS Ltd., Hillerød, Denmark). Protein content estimation was performed in triplicates, and a factor of 6.25 was used with the $\mathrm{N}$ content [27]. The values obtained were then averaged.

\subsection{Total Crude Fat Extraction Using the Soxhlet Method}

Total crude fat was extracted from the seeds using a Soxhlet extractor, which was developed by Franz von Soxhlet in 1879 for the extraction of lipids from a solid material (seeds) to determine the percentage of crude fat.

Seeds were ground to a particle size of $<0.1 \mathrm{~mm}$ in liquid nitrogen using a mortar and pestle. Approximately $1 \mathrm{~g}$ of crushed seeds were weighed and transferred to a $28 \mathrm{~mm} \times 100 \mathrm{~mm}$ cellulose thimble (No. 84; Advante Corp., Tokyo, Japan). Subsequently, approximately $100 \mathrm{~mL}$ of diethyl ether (boiling point: $60-80^{\circ} \mathrm{C}$ ) was boiled in a Soxhlet apparatus ( $100 \mathrm{~mL}$ round-bottomed flask) fitted with a condenser, using an electrothermal heater (EAM 9202-06; Tops Misung Scientific Co., Seoul, Korea), and crude fat was extracted under reflux with petroleum ether for $16 \mathrm{~h}(3-4$ cycles $/ \mathrm{h}$ ) according to the International Official Methods of Analysis (AOAC) section 920.39 [27]. The water cooler (HB-207M; Hanbaek Corp., Bucheon, Korea) was maintained at $3-4{ }^{\circ} \mathrm{C}$ using a solvent mixture of methanol:water (1:9). Upon completion of extraction, the defatted sample was removed. The distillation flask containing the total crude fat was then oven-dried at $50{ }^{\circ} \mathrm{C}$ for $15 \mathrm{~min}$ and cooled in a desiccator. The flask and its contents were then weighed.

All extractions were performed in quadruplicates, and the mean crude fat content was calculated using the following formula and expressed as a percentage of seed weight.

$$
\text { Total crude fat content }(\%)=\left[\mathrm{W}_{3}-\mathrm{W}_{2} / \mathrm{W}_{1}\right] \times 100
$$

where $W_{1}$ is original weight of the sample, $W_{2}$ is weight of the empty flask, and $W_{3}$ is weight of the flask and fat. 


\subsection{Germination Test and Index}

Germination test under different temperature regimes as described in Section 2.8 were performed on 14 April 2020. Four replicates with ten seeds each per condition were sown on the surface of 1\% agar (Sigma-Aldrich, St. Louis, MO, USA) in $60 \mathrm{~mm} \times 15 \mathrm{~mm}$ plastic Petri dishes (SPL Life Sciences Co. Ltd., Pocheon, Korea). The number of germinated seeds was counted on weekdays for five weeks. Germinated seeds, with radicle length of $0.5-1 \mathrm{~mm}$, were then observed under the digital microscope. The experiments were terminated when no further germination was observed for over one week.

Final viability of non-germinated seeds was verified using the triphenyltetrazolium chloride (TTC) test. The non-germinated seeds were immersed in a $1 \%$ aqueous solution of 2,3,5-triphenyl-2H-tetrazolium chloride at $30^{\circ} \mathrm{C}$ overnight (12 h). We identified the viable and nonviable seeds using a microscope; pink- or red-stained embryos were considered viable, whereas unstained embryos were considered nonviable [18].

The germination index was calculated based on the germination percentage (GP), mean germination time (MGT), and $50 \%$ of the final germination $\left(\mathrm{T}_{50}\right)$. GP was calculated using the following formula [26]:

$$
\mathrm{GP}=(\mathrm{N} / \mathrm{S}) \times 100,
$$

where $\mathrm{N}$ is the sum of the number of seeds germinated until the end of the germination test and $\mathrm{S}$ is the total number of seeds.

The final germination percentage (FGP) was calculated using the total number of sow seeds, excluding dead seeds (unstained embryos), as the parameter.

MGT was estimated using the following formula [28]:

$$
\mathrm{MGT}=\Sigma\left(\mathrm{T}_{\mathrm{i}} \times \mathrm{N}_{\mathrm{i}}\right) / \mathrm{N},
$$

where $T_{i}$ is the number of days from the beginning of germination until day $T$ and $\mathrm{N}_{\mathrm{i}}$ is the number of seeds germinated on day $\mathrm{T}$.

$\mathrm{T}_{50}$ was determined using the formula given below [29]:

$$
\mathrm{T}_{50}=\mathrm{t}_{\mathrm{i}}+\left[\left\{(\mathrm{N}+1) / 2-\mathrm{n}_{\mathrm{i}}\right\} \times\left(\mathrm{t}_{\mathrm{j}}-\mathrm{t}_{\mathrm{i}}\right)\right] /\left(\mathrm{n}_{\mathrm{j}}-\mathrm{n}_{\mathrm{i}}\right),
$$

where $t_{i}$ is time period before reaching $50 \%$ of the final germination, $n_{i}$ is the number of seeds that emerged at $t_{i}, t_{j}$ is the time after $t_{i}$, and $n_{j}$ is the number of seeds that emerged at $t_{j}$.

\subsection{Temperature Regimes}

\subsubsection{Experiment 1: Seven Constant Temperature Regimes}

Each plastic Petri dish was placed in a transparent plastic box and kept in a germination chamber (TGL-1S; Espec Mic Corp., Aichi, Japan) and then in a growth chamber (TGC-130H; Espec Mic Corp., Aichi, Japan) at $5^{\circ} \mathrm{C}, 10{ }^{\circ} \mathrm{C}, 15^{\circ} \mathrm{C}, 20^{\circ} \mathrm{C}, 25^{\circ} \mathrm{C}, 30^{\circ} \mathrm{C}$, and $35^{\circ} \mathrm{C}$, with $12: 12 \mathrm{~h}$ (light:dark) cycles for all temperature regimes. The seeds were sown in agar medium and examined for germination, as described in Section 2.7.

\subsubsection{Experiment 2: Fifty-Nine Different Temperature Regimes}

The base temperature $(\mathrm{Tb})$ was defined using a linear model of development rate against temperature. To determine the base temperature, the seeds were incubated in a microthermal gradient plate (ONSOL Corp., Suwon, Korea) with a 12:12 h (light:dark) photoperiod (white fluorescent light: $40 \pm 10 \mu \mathrm{mol} \cdot \mathrm{m}^{-2} \cdot \mathrm{s}^{-1}$ ). The thermal gradient plate (TGP) was based on 60 temperature combinations of $10 \times 6$ (horizontal $\times$ vertical) with a temperature range of $7-43{ }^{\circ} \mathrm{C}$ at $4{ }^{\circ} \mathrm{C}$ intervals and $5-30{ }^{\circ} \mathrm{C}$ at $5{ }^{\circ} \mathrm{C}$ intervals. However, during the evaluation process, an abnormal temperature occurred in one cell, and it was recorded in the data logger. It was excluded because the data were not reliable outside the evaluation temperature range $\left( \pm 1^{\circ} \mathrm{C}\right)$. Therefore, only 59 conditions were used for 
data analysis. The Petri dishes were placed in a completely randomized design on the TGP. There are instructions found in 2.7 for agar medium conditions, germination checking, etc.

\subsection{Statistical Analysis}

Data were analyzed using SPSS 23.0 (SPSS Inc., Chicago, IL, USA). Statistically significant differences between the variables were determined using one-way analysis of variance with Tukey's multiple range tests assessed at $p<0.05$. Linear regression plots and graphs were generated using SigmaPlot 12.5 software (Systat Software Inc., San Jose, CA, USA).

\section{Results}

\subsection{Seed Morphology}

P. pusanensis plants exhibit indefinite inflorescences (Figure 1a). The flowers have inferior ovaries (Figure 1b) with ovules inside. When the ovaries mature, their color changes from green to reddish brown, and they become dry and release seeds (Figure 1c,d). The seeds were glossy, flat and round, and $1.05 \pm 0.21 \mathrm{~mm}$ (length) $\times 0.96 \pm 0.17 \mathrm{~mm}$ (width) in size, with light or dark brown testae (Figure 1e,f) and undeveloped embryos at dispersal (Figure 1g). The E:S ratios at dispersal and just before germination were $0.44 \pm 0.05$ and $0.69 \pm 0.08$, respectively, indicating an increase of $56.0 \pm 2 \%$ during germination. After the embryo developed, the radicle emerged through the hilum of the seed (Figure 1h).

\subsection{Seed Characteristics}

When the seeds reached an ERH of $17.58 \%$, the seed MC and 1000-seed weight were $4.32 \pm 0.05 \%$ and $0.1188 \pm 0.0011 \mathrm{~g}$, respectively. Additionally, the total crude fat and protein contents of the seeds with a FGP $\geq 85 \%$ were $22.43 \pm 3.32 \%$ and $15.94 \pm 0.09 \%$, respectively.

\subsection{Constant Temperature Regimes}

The cumulative germination in P. pusanensis seeds was not affected at $35^{\circ} \mathrm{C}$. However, the GP varied from 0.0 to $90.0 \pm 7.07 \%$ for temperature regimes ranging from $5{ }^{\circ} \mathrm{C}$ to $35^{\circ} \mathrm{C}$. Further, the GP increased from $5{ }^{\circ} \mathrm{C}$ to $15^{\circ} \mathrm{C}$, but began to decrease with a further increase in temperature (Figure 2). The TTC test was used to determine the number of viable and non-viable seeds, and it reflected the average FGP. The highest FGP $(94.38 \pm 3.29 \%)$ was observed five weeks after sowing at $15^{\circ} \mathrm{C}$.

The germination index of the seeds was determined using the MGT and the inverse of the time required to reach $20 \%, 50 \%$, and $80 \%$ of the FGP $\left(1 / \mathrm{T}_{(\mathrm{FGP})}, \mathrm{d}^{-1}\right)$. Moreover, $1 / \mathrm{T}_{(\mathrm{FGP})}$ was plotted as a function of temperature and was analyzed using linear regression. When $1 / T_{(G P)}=0$, we estimated the base temperature $\left(T_{b}\right)$.

P. pusanensis seeds exhibited the fastest response time, with $\mathrm{T}_{20}=4.50$ days, $\mathrm{T}_{50}=5.38$ days, and $\mathrm{T}_{80}=7.80$ days at $25^{\circ} \mathrm{C}$, and inverse values of $0.222,0.186$, and 0.128 , respectively (Figure 3 ). Similar values were obtained for the germination index of MGT. However, at $5{ }^{\circ} \mathrm{C}$ and $25^{\circ} \mathrm{C}$, the germination index could not be determined because of a low GP. By contrast, the slowest response was observed at $10{ }^{\circ} \mathrm{C}(0.0432)$ in the sub-optimal range. A $\mathrm{T}_{\mathrm{b}}$ value of $3.98 \pm 0.65^{\circ} \mathrm{C}$ was obtained when linear regression plots were fitted with $1 / \mathrm{T}_{(\mathrm{FGP})}$. These results demonstrated that a constant temperature of $15{ }^{\circ} \mathrm{C}$ affected germination in P. pusanensis. Furthermore, the initial GP and $T_{50}$ were at 5 days after sowing (data not shown) and 9.2 days, respectively. 

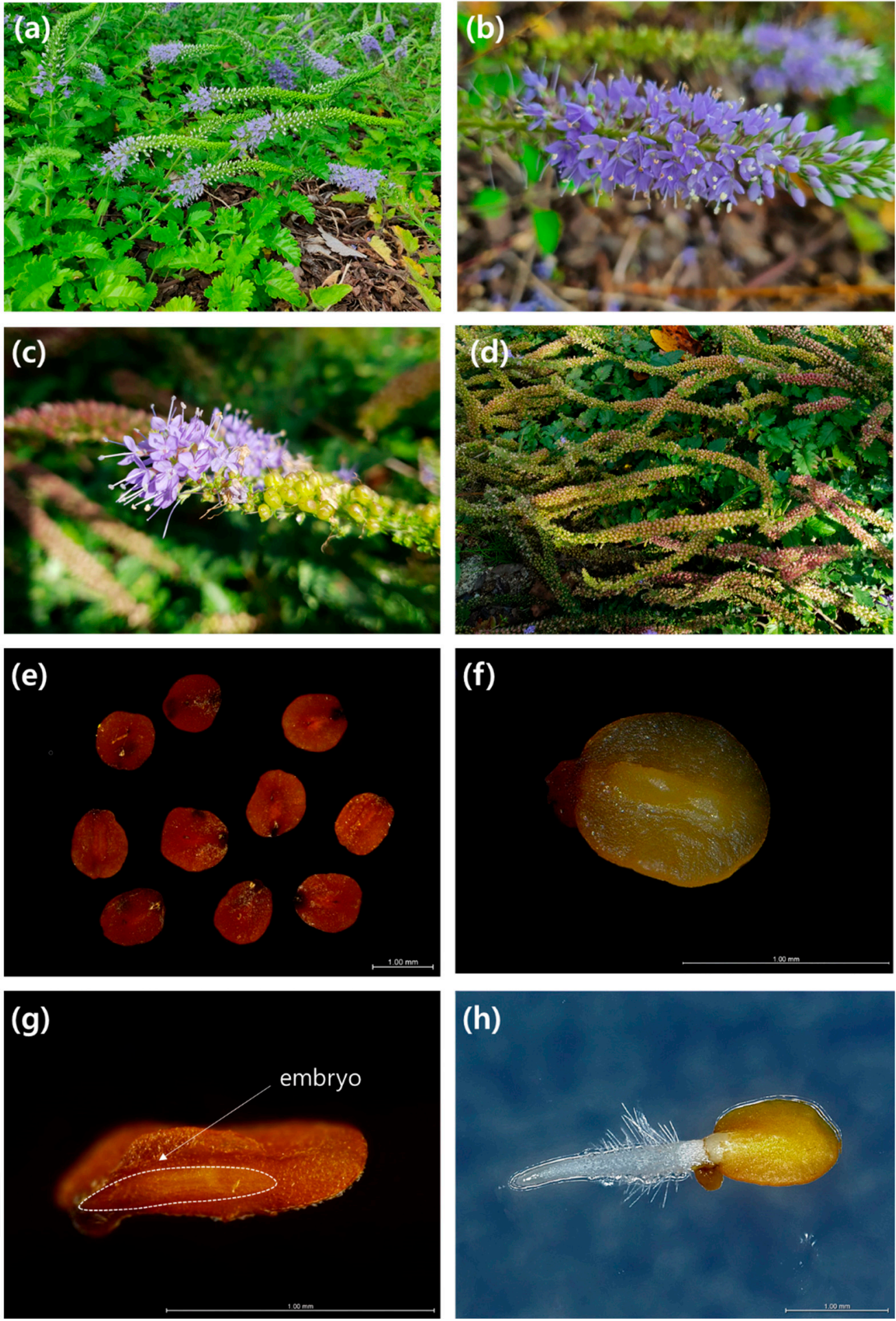

Figure 1. Morphology of Pseudolysimachion pusanensis (Y. N. Lee) Y. N. Lee. (a) A field of P. pusanensis at Bonghwa-gun. (b) Flowers on the basal inflorescence bloomed on 3 August, 2019. (c) Flowers on the distal inflorescence bloomed on September 30, 2019. (d) The seed color in the ovaries varied from green to brown on October 20, 2019. (e) Seeds at dispersal. (f) Digital image of a seed. Cross-section of a seed showing $(\mathrm{g})$ an undeveloped embryo and $(\mathbf{h})$ radicle emergence; scale bar $=1 \mathrm{~mm}$ (applies to $(\mathbf{e}-\mathbf{h}))$. 


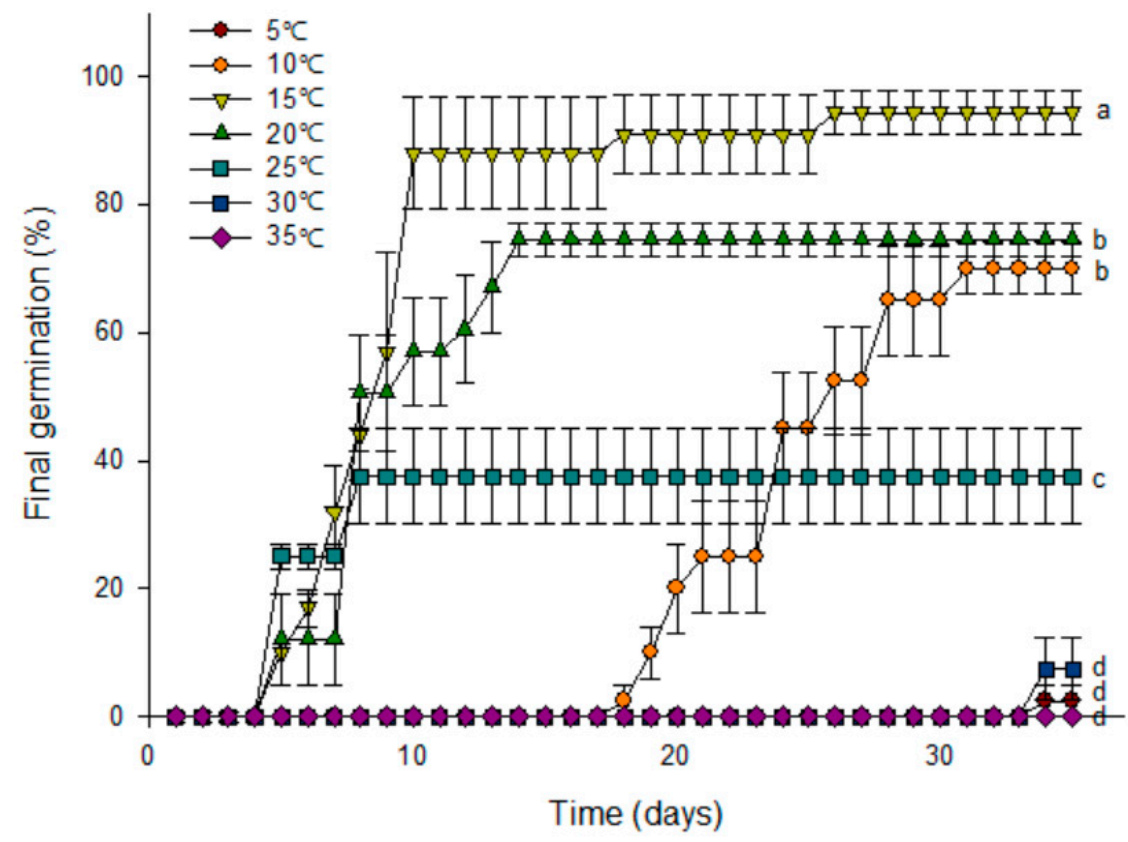

Figure 2. Final germination of $P$. pusanensis seeds at constant temperature regimes ranging from $5{ }^{\circ} \mathrm{C}$ to $35^{\circ} \mathrm{C}$. Bars represent mean $\pm \mathrm{SE}(n=4)$. Same lowercase letters above columns indicate no significant difference $(p<0.001)$.

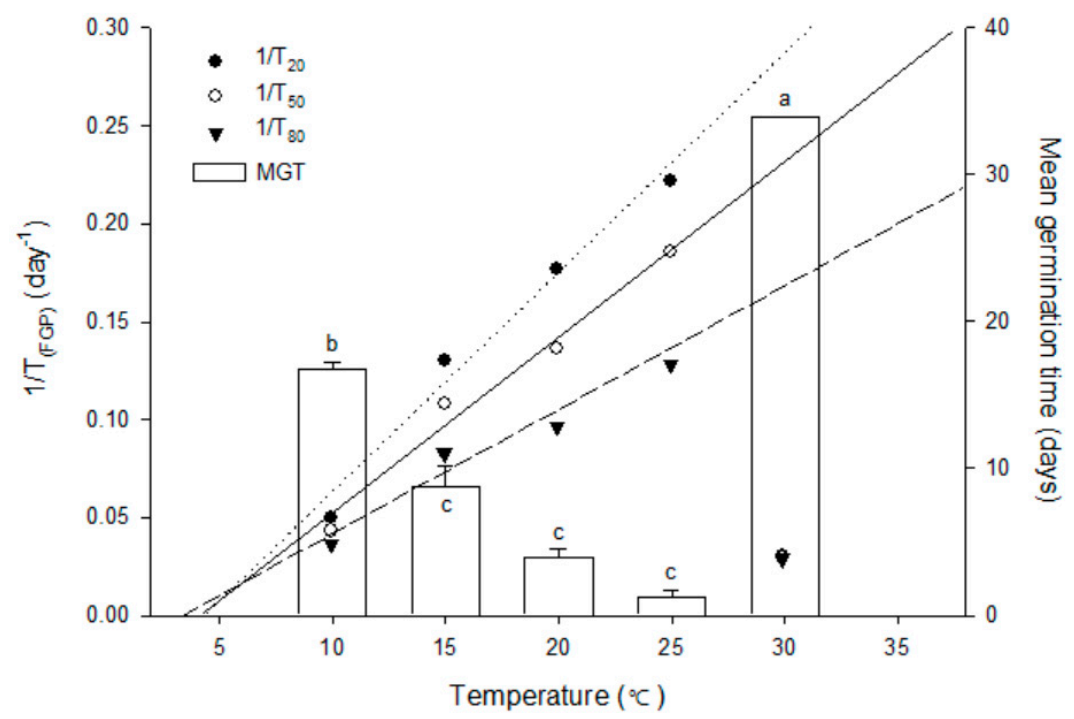

Figure 3. Effect of constant temperature regimes $\left(5{ }^{\circ} \mathrm{C}, 10{ }^{\circ} \mathrm{C}, 15^{\circ} \mathrm{C}, 20{ }^{\circ} \mathrm{C}, 25^{\circ} \mathrm{C}, 30{ }^{\circ} \mathrm{C}\right.$, and $\left.35^{\circ} \mathrm{C}\right)$ on the inverse of the time required to reach the FGP $\left(1 / \mathrm{T}_{(\mathrm{FGP})}\right)$ and mean germination time, revealing linear relationships between $1 / \mathrm{T}_{(\mathrm{FGP})}$ and temperature in the sub-optimal range. The dotted line, solid line, and short dashed line indicate the linear regression for $1 / \mathrm{T}_{20}, 1 / \mathrm{T}_{50}$, and $1 / \mathrm{T}_{80}$, respectively, passing through the base temperature $\left(\mathrm{T}_{\mathrm{b}}\right)$. The $\mathrm{T}_{\mathrm{b}}$ values were $4.56{ }^{\circ} \mathrm{C}, 4.68^{\circ} \mathrm{C}$, and $2.69{ }^{\circ} \mathrm{C}$ for $1 / \mathrm{T}_{20}, 1 / \mathrm{T}_{50}$, and $1 / \mathrm{T}_{80}$, respectively. Vertical bars indicate standard errors $(n=4)$. Same lowercase letters indicate no significant difference $(p<0.001)$.

\subsection{Alternating Temperature Regimes}

To verify whether constant temperature regimes affect germination, a TGP was used to conduct different temperature experiments, with 58 alternating and constant $\left(15^{\circ} \mathrm{C}\right)$ temperature conditions. The highest FGP $(86.6 \%)$ was observed at $15^{\circ} \mathrm{C}$ in the temperature regime (Figure 4a), with a $\mathrm{T}_{50}$ value of $9-10 \mathrm{~d}\left(1 / \mathrm{T}_{50}: 0.10-0.11 \mathrm{~d}^{-1}\right)$ (Figure $\left.4 \mathrm{~b}\right)$. Most seeds germinated up to $50 \%$ until the temperature reached $23{ }^{\circ} \mathrm{C}$, but the FGP markedly 
decreased above $27^{\circ} \mathrm{C}$. Furthermore, the greater the temperature difference between light (day) and dark (night) periods, the lower the FGP (Figure 5).

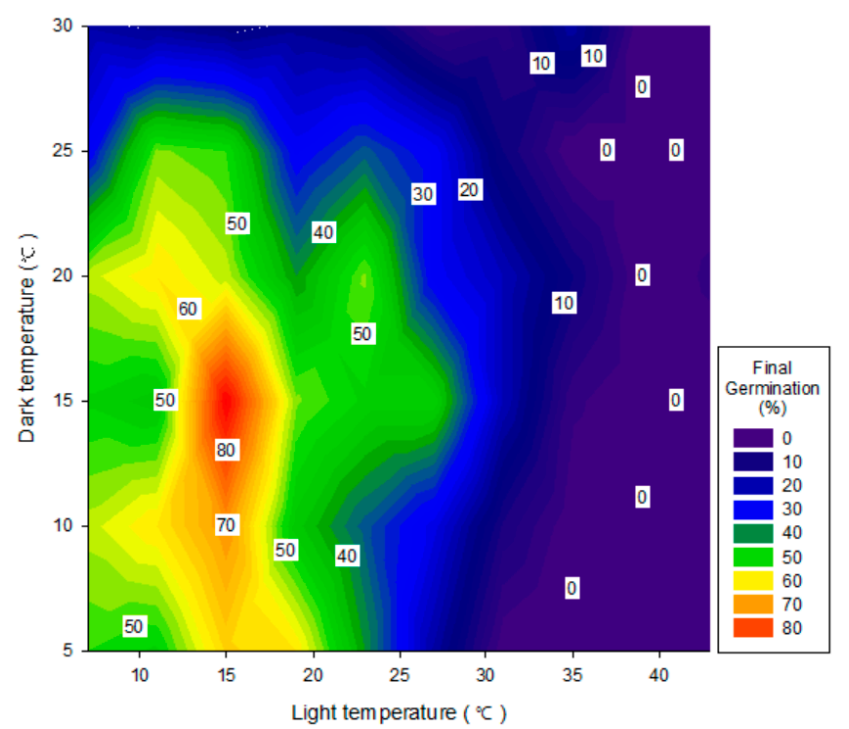

(a)

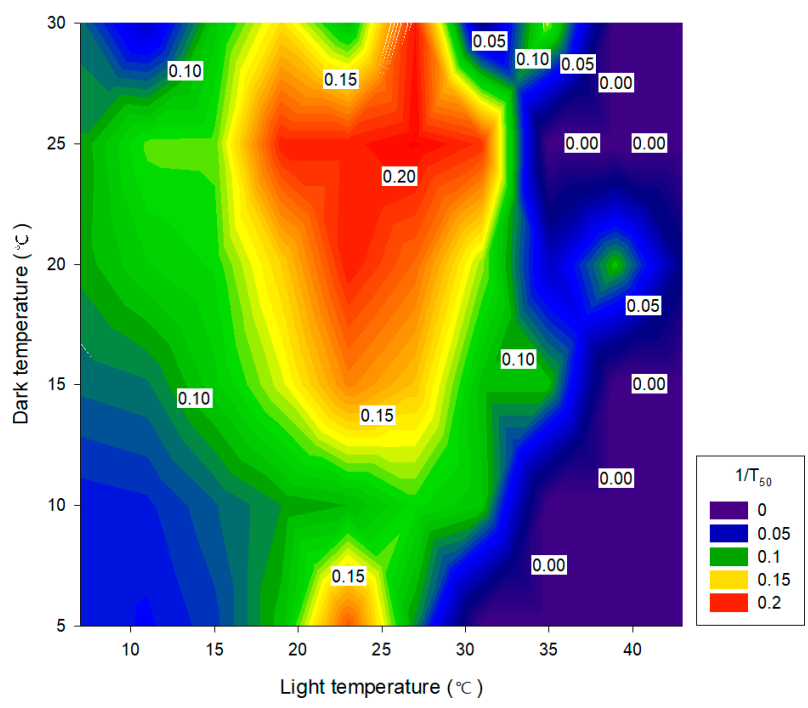

(b)

Figure 4. Germination response revealed by the analysis of FGP and the inverse of the number of days required to reach $50 \%$ of the FGP $\left(1 / \mathrm{T}_{50}\right)$ of the seeds exposed to alternating temperature regimes using a thermal gradient plate: (a) FGP (\%) at different temperatures; (b) $1 / \mathrm{T}_{50}$ at different temperatures ranging from $5^{\circ} \mathrm{C}$ to $43^{\circ} \mathrm{C}$.

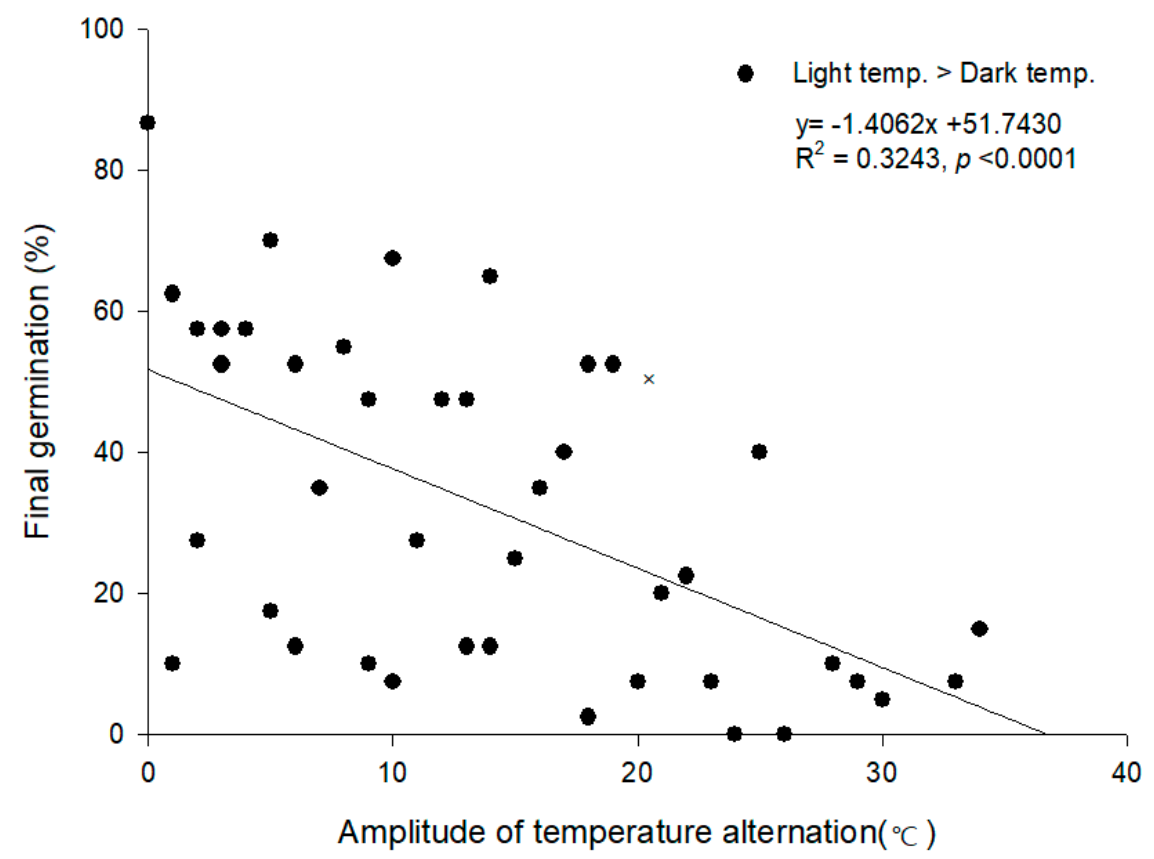

Figure 5. Relationship between the amplitude of temperature alternation $\left({ }^{\circ} \mathrm{C}\right)$ and FGP $(\%)$ determined using the thermal gradient plate, with the temperatures during the light period being higher than those during the dark period.

\section{Discussion}

\subsection{Seed Morphology and Characteristics}

P. pusanensis, a rare species due to its small population, is classified as a protected species. It grows lying on the ground at short heights and has light blue flowers in racemes. The flowers at the end of the inflorescences stick together. The seeds in this study were collected one month after the inflorescences bloomed and all ovaries turned 
from green to brown. At this time, some seeds were released from the basal flowers of an inflorescence. The shape of the seeds was as flat and round as a coin, and their average size was $1.05 \times 0.96 \mathrm{~mm}(\mathrm{~L} \times \mathrm{W})$. The E:S ratio during dispersal was 0.44 . If the E:S ratio is 0.5 or less, the dormancy type is morphological dormancy (MD) and MPD [30]. Song et al. [10] found that the average length of V. pusanensis seeds collected from Pocheon on 23 September 2016 was $1.14 \mathrm{~mm}$. Additionally, the seeds were of dwarf type (size: 0.3-2.0 $\mathrm{mm}$ ) with an axile embryo [31]. Physiological dormancy in the embryo or tissue surrounding the embryo, which secretes a growth inhibitory agent to inhibit germination, was not observed, and because the E:S ratio increased, the dormancy was judged as morphological dormancy. The analysis results of the internal and external morphology showed that there was no visible structural difference, but the time of seed collection and the environmental conditions of the collection area (climate, precipitation, etc.) contributed to seed formation. Further, P. pusanensis had a high germination percentage at $15^{\circ} \mathrm{C}$ due to the effect of breaking MD. During seed production, the environment has a significant impact on the behavior of progeny seeds [32]. The environmental conditions (temperature) near the parent tree can affect the germination percentage of their offspring, and can even affect later generations [33,34]. This has been demonstrated in wild and cultivated species. Further, the temperature difference in the parental environment can affect the degree of dormancy and germination behavior [35]. In addition to temperature changes, the altitude and season have been found to affect seed dormancy and offspring seed characteristics [32].

In this study, the MC of dried P. pusanensis seeds after collection was $4.32 \%$, and the 1000 seed weight was $0.1188 \mathrm{~g}$; these parameters were used to determine the number of seeds to be stored in the seed bank. MC is the most important factor responsible for maintaining seed viability in seed banks, and plays critical roles in determining the seed longevity [36]. Even small changes in the MC have remarkable effects on the shelf life of seeds [37]. Orthodox seeds are suitable for long-term storage if they have an MC of less than $8 \%$ at a $15 \%$ RH [38]. Furthermore, seeds stored at $4-5 \%$ MC are unaffected by seed storage fungi [39]. According to the present study, the MC of P. pusanensis seeds was less than $8 \%$, which is suitable for long-term storage. According to the Kew seed information database [30], the storage behavior of 76 species of the Veronica genus was revealed. Among the 76 species, $98.68 \%$ were orthodox seeds, which could be stored in the seed bank for more than one year, while the storage of the remaining $1.32 \%$ was uncertain. Therefore, P. pusanensis seeds were considered orthodox.

In this study, for the first time, the fat and protein contents of P. pusanensis seeds were reported. The Kew seed information database has not reported any information about P. pusanensis in the genera Veronica and Pseudolysimachion. In the genus Veronica, 116 species were investigated for their storage behavior, mean 1000-seed weight, germination information, and oil and protein content. In the genus Pseudolysimachion, two species were investigated for their storage behavior and germination information. Of these, only three had information on their total crude fat and protein contents. The species with the highest total crude fat content were Veronica spicata L. (31.0\%), Veronica longifolia L. (18.5\%), and Veronica salina Schur (15.8\%). The total crude protein content decreased in the following order: Veronica longifolia L. $(27.5 \%)>$ Veronica spicata L. $(26.2 \%)>$ Veronica salina Schur (21.4\%). The total crude fat content of P. pusanensis was intermediate $(22.4 \%)$, while its total crude protein content was the lowest, at $15.9 \%$.

Information of seed characteristics is essential for the germination of stored seeds and is necessary to manage seed banks. This is because storage lipids are metabolized in seeds that require high energy for germination [40]. Furthermore, seed storage proteins are synthesized to serve as sources of carbon, nitrogen, and sulfur for the next generation of plants [41]. Additionally, the components of a seed (proteins, lipids, and starch) are related to seed longevity. When fat is oxidized due to aging during storage [42], the total crude fat content varies, thereby reducing the seed viability Therefore, to continuously maintain the viability of P. pusanensis seeds in the seed bank, seed characteristics that affect the lifespan and germination of seeds must be continuously monitored; additionally, the renewal cycle 
should be determined to maintain viability. Seeds stored in the seed bank will lose their viability and longevity during storage. Since the longevity of seeds and the time it takes for the viability to decrease by $50 \%$ differ for each species, it is necessary to establish a renewal cycle for each species so that seeds in a seed bank can be efficiently managed. We are currently conducting follow-up studies to reveal the lifespan and renewal cycle for the species conservation of P. pusanensis.

\subsection{Temperature Regimes}

During condition 7 of the constant temperature experiment $\left(5^{\circ} \mathrm{C}, 10^{\circ} \mathrm{C}, 15^{\circ} \mathrm{C}, 20^{\circ} \mathrm{C}\right.$, $25{ }^{\circ} \mathrm{C}, 30{ }^{\circ} \mathrm{C}, 35^{\circ} \mathrm{C}$ ), the seeds showed $94.38 \%$ of FGP at $15{ }^{\circ} \mathrm{C}$, suggesting that the appropriate germination temperature for the seeds of P. pusanensis was $15^{\circ} \mathrm{C}$. In addition, it is considered to promote germination by breaking morphological dormancy. According to a previous study, $V$. pusanensis seeds showed $>80 \%$ FGP in the temperature range of $15-25{ }^{\circ} \mathrm{C}$. Comparing the germination response, P. pusanensis seeds exhibited a similar trend in GP, which increased with a certain increase in temperature and then decreased. However, at $25{ }^{\circ} \mathrm{C}$, the temperature reactions were different from the previous study. Further, at $15{ }^{\circ} \mathrm{C}, 20^{\circ} \mathrm{C}$, and $25^{\circ} \mathrm{C}$, P. pusanensis showed a FGP of $94.38 \%, 74.44 \%$, and $37.5 \%$ and MGT of $12.8 \mathrm{~d}, 3.9 \mathrm{~d}$, and $1.2 \mathrm{~d}$, respectively. However, previous studies did not report the exact value, and the range was inferred graphically [10]. At $15{ }^{\circ} \mathrm{C}, 20^{\circ} \mathrm{C}$, and $25{ }^{\circ} \mathrm{C}$, the GP was reported to be $80-94.0 \%$, more than $94.0 \%$, and more than $94.0 \%$, and the MGT was less than $10 \mathrm{~d}, 4.6 \mathrm{~d}$, and $4.8 \mathrm{~d}$, respectively. Although the two studies differed in the number of collection areas and the type of medium, it can be inferred that the germination response, such as germination (\%) and germination rate (MGT, $\mathrm{T}_{50}$ ), was observed at $15{ }^{\circ} \mathrm{C}$ in both studies. Further, there was a difference in the treatment at $20^{\circ} \mathrm{C}$ and $25^{\circ} \mathrm{C}$, and, in particular, the opposite response was shown at $25^{\circ} \mathrm{C}$. Based on the results of the constant temperature experiment in the two studies, the most suitable temperature for breaking morphological dormancy and germination was judged to be $15-20{ }^{\circ} \mathrm{C}$. These differences may be associated with differences in the GP across sampling areas. The percentage of seed germination for a species has been reported to be associated with specific environmental characteristics, including the total amount of precipitation and the variation in annual precipitation in the distributional range of the species [43-45]. Heteropappus arenarius Kitam., a species native to Korea, collected from different latitudes and longitudes, exhibited a different GP with temperature [45]. A Korean endemic species, Abies koreana Wilson, exhibited significantly different germination percentages and rates among populations [46].

Differences in the FGP of P. pusanensis may be related because of different distribution areas, and its indeterminate inflorescence. P. pusanensis seeds used for this study were collected from ovaries, except the basal flowers of the inflorescence of the mother plants. Furthermore, seeds produced at different heights of the parent plant exhibit differences in the level of dormancy and seed size, resulting in differences in dormancy breaking and germination requirements $[47,48]$. Seeds harvested from inflorescences at three different positions at the same time revealed that those collected from the bottom of the inflorescence (first seeds) exhibited a higher GP and fewer abnormalities than those collected from the second and third positions, which may exhibit different germination characteristics [49]. Chelidonium majus subsp. asiaticum Hara and 39 species have been reported to exhibit different germination characteristics depending on their location [18].

During condition 59 of the temperature experiment using TGP, the dormancy break and amplitude of temperature difference were negatively correlated. In the alternate temperature experiment, the lower the amplitude of temperature, the greater the dormancy breaks and the higher the possibility of germination (60.0\%). Among the 59 conditions, in 11 conditions, P. pusanensis seeds had an FGP of $0-10 \%$, and the night temperature had no effect. 


\section{Conclusions}

In summary, according to the two temperature regime results, $15-20{ }^{\circ} \mathrm{C}$ was redefined as the optimum germination temperature range for P. pusanensis seeds, and it can be concluded that the smaller the amplitude of temperature alternation, the greater the morphological dormancy break, thereby increasing the possibility of germination. Additionally, theoretical conclusions were acquired on the basic characteristics and germination of $P$. pusanensis seeds. These results for P. pusanensis seeds stored in a seed bank provide useful data for ecological restoration and can also be applied for storage management. The findings will also be significant for the native plant horticulture industries.

Author Contributions: Conceptualization, M.-H.L. and C.-S.N.; methodology, M.-H.L.; software, M.-H.L.; formal analysis, M.-H.L.; investigation, M.-H.L., J.-H.L., C.-H.P., and J.-H.K.; resources, M.-H.L. and J.-H.K.; data curation, M.-H.L. and J.-H.L.; writing-original draft preparation, M.-H.L.; writing-review and editing, M.-H.L.; project administration, C.-S.N.; funding acquisition, C.-S.N. All authors have read and agreed to the published version of the manuscript.

Funding: This study was supported by the R\&D Program for Forest Science Technology (Project No. 2021399B10-2125-CA02) of the Korea Forest Service (Korea Forestry Promotion Institute).

Institutional Review Board Statement: Not applicable.

Informed Consent Statement: Not applicable.

Data Availability Statement: Not applicable.

Acknowledgments: We gratefully acknowledge Jun-Hyeok Kim for assistance with seed collection and observations.

Conflicts of Interest: The authors declare no conflict of interest.

\section{References}

1. Albach, D.C.; Martínez-Ortega, M.M.; Chase, M.W. Veronica: Parallel morphological evolution and phylogeography in the Mediterranean. Plant Syst. Evol. 2004, 246, 177-194. [CrossRef]

2. Albach, D.C.; Martínez-Ortega, M.M.; Delgado, L.; Weiss-Schneeweiss, H.; Özgökce, F.; Fischer, M.A. Chromosome numbers in Veroniceae (Plantaginaceae): Review and several new counts 1. Ann. Mo. Bot. Gard. 2008, 95, 543-566. [CrossRef]

3. Garnock-Jones, P.; Albach, D.; Briggs, B.G. Botanical names in southern hemisphere Veronica (Plantaginaceae): Sect. Detzneria, sect. Hebe, and sect. Labiatoides. Taxon 2007, 56, 571-582. [CrossRef]

4. Albach, D.C.; Meudt, H.M.; Oxelman, B. Piecing together the "new" Plantaginaceae. Am. J. Bot. 2005, 92, 297-315. [CrossRef] [PubMed]

5. Kosachev, P.; Mayland-Quellhorst, E.; Albach, D.C. Hybridization among species of Veronica subg. Pseudolysimachium in the Altai detected by SRAP markers. Nord. J. Bot. 2019, 37, 1-23.

6. Hawke, R.G. Comparative studies of Veronica and Veronicastrum. Plant Eval. Notes 2010, 33, 1-8.

7. Lee, Y.N. New taxa of Korean flora. Bull. Korea Plant Res. 2004, 4, 2-29.

8. Lee, Y.N. New plant names on flora of Korea, revised new ed. Bull. Korea Plant Res. 2005, 5, 40-64.

9. Korea Forest Service. Korea Biodiversity Information System 2010. Available online: http://www.nature.go.kr/ (accessed on 28 October 2021).

10. Song, S.J.; Shin, U.S.; Oh, H.J.; Kim, S.Y.; Lee, S.Y. Seed germination responses and interspecific variations to different incubation temperatures in eight Veronica species native to Korea. Korean J. Hortic. Sci. Technol. 2019, 37, $20-31$.

11. Oh, H.J.; Shin, U.S.; Song, S.J.; Kim, J.H.; Kim, S.Y.; Suh, G.U. Growth and flowering characteristics of 20 Veronica species. Flower Res. J. 2019, 27, 308-317. [CrossRef]

12. Lim, S.H. Growth and flowering responses of Korean native Veronica rotunda and Veronica longifolia to cold treatment and light conditions. Master's Thesis, Seoul National University, Seoul, Korea, 2019.

13. Kim, S.H.; Kim, J.H.; Oh, H.J.; Kim, S.Y.; Suh, G.U. Vegetative propagation of Veronica dahurica and Veronica pusanensis by stem cuttings with auxins. Rhizosphere 2021, 17, 100315. [CrossRef]

14. Na, C.S.; Baek, S.G.; Yang, S.Y.; Park, C.Y.; Kim, J.H.; Lee, M.H.; Park, Y.S. Species-specific seed vigor test of aging chive for restoration and regional adaptation under climate change. Appl. Ecol. Environ. Res. 2013, 18, 683-695. [CrossRef]

15. Hay, F.R.; Probert, R.J. Advances in seed conservation of wild plant species: A review of recent research. Conserv. Physiol. 2013, 1, 1-11. [CrossRef] [PubMed]

16. Khoury, C.; Laliberté, B.; Guarino, L. Trends in ex situ conservation of plant genetic resources: A review of global crop and regional conservation strategies. Genet. Resour. Crop. Evol. 2010, 57, 625-639. [CrossRef]

17. Merritt, D.J.; Dixon, K.W. Restoration seed banks-A matter of scale. Science 2011, 332, 424-425. [CrossRef] [PubMed] 
18. Baskin, C.C.; Baskin, J.M. Seeds: Ecology, Biogeography, and Evolution of Dormancy and Germination; Academic Press: San Diego, CA, USA, 2014.

19. Donohue, K.; Rubio de Casas, R.; Burghardt, L.; Kovach, K.; Willis, C.G. Germination, postgermination adaptation, and species ecological ranges. Annu. Rev. Ecol. Evol. Syst. 2010, 41, 293-319. [CrossRef]

20. Wagmann, K.; Hautekèete, N.C.; Piquot, Y.; Meunier, C.; Schmitt, S.E.; Van Dijk, H. Seed dormancy distribution: Explanatory ecological factors. Ann. Bot. 2012, 110, 1205-1219. [CrossRef] [PubMed]

21. Guerin, J.; Thorpe, M.; Duval, D.; Jusaitis, M.; Ainsley, P. Germination of Veronica parnkalliana seeds in response to seasonal and fire cues. In Proceedings of the 5th Global Botanic Gardens Congress, Dunedin, New Zealand, 20-25 October 2013.

22. Luo, T.; Xian, M.; Khan, M.N.; Hu, L.; Xu, Z. Estimation of base temperature for germination of rapeseed (Brassica napus L.) using different models. Int. J. Agric. Biol. 2018, 20, 524-530. [CrossRef]

23. Batlla, D.; Benech-Arnold, R.L. A framework for the interpretation of temperature effects on dormancy and germination in seed populations showing dormancy. Seed Sci. Res. 2015, 25, 147-158. [CrossRef]

24. Ranal, M.A.; Santana, D.G.D. How and why to measure the germination process? Braz. J. Bot. 2006, 29, 1-11. [CrossRef]

25. International Seed Testing Association. International Rules for Seed Testing. Rules 1985. Seed Sci. Technol. 1985, 13, $299-513$.

26. International Seed Testing Association (ISTA). International Rules for Seed Testing 2015; The International Seed Testing Association: Bassersdorf, Switzerland, 2015.

27. Association of Official Analytical Chemists (AOAC). Official Methods of Analysis AOAC International Methods 920.39; Association of Official Analytical Chemists (AOAC): Gaithersburg, MD, USA, 2000.

28. Ellis, R.H.; Roberts, E.H. The quantification of ageing and survival in orthodox seeds. Seed Sci. Technol. 1981, 9, $373-409$.

29. Coolbear, P.; Francis, A.; Grierson, D. The effect of low temperature pre-sowing treatment on the germination performance and membrane integrity of artificially aged tomato seeds. J. Exp. Bot. 1984, 35, 1609-1617. [CrossRef]

30. Seed Information Database: Royal Botanic Gardens, Kew. Available online: http://data.kew.org/sid/ (accessed on 26 November 2021).

31. Schopmeyer, C.S. Seeds of woody plants in the United States. In Agriculture Handbook; No. 450; US Department of Agriculture: Washington, DC, USA, 1974.

32. Penfield, S.; MacGregor, D.R. Effects of environmental variation during seed production on seed dormancy and germination. J. Exp. Bot. 2017, 68, 819-825. [CrossRef] [PubMed]

33. Thomas, T.H.; Raper, C.D. Seed germinability as affected by the environmental temperature of the mother plant. Tob. Sci. 1975, 19, 98-100.

34. Chen, M.; MacGregor, D.R.; Dave, A.; Florance, H.; Moore, K.; Paszkiewicz, K.; Smirnoff, N.; Graham, I.A.; Penfield, S. Maternal temperature history activates Flowering Locus $\mathrm{T}$ in fruits to control progeny dormancy according to time of year. Proc. Natl. Acad. Sci. USA 2014, 111, 18787-18792. [CrossRef]

35. Huang, Z.; Footitt, S.; Tang, A.; Finch-Savage, W.E. Predicted global warming scenarios impact on the mother plant to alter seed dormancy and germination behaviour in Arabidopsis. Plant Cell Environ. 2018, 41, 187-197. [CrossRef] [PubMed]

36. Bewley, J.D.; Black, M. Biochemistry of Seeds in Relation to Germination; Springer: Berlin/Heidelberg, Germany, 1982 ; Volume 2.

37. Vertucci, C.W.; Roos, E.E. Theoretical basis of protocols for seed storage. Plant Physiol. 1990, 94, 1019-1023. [CrossRef] [PubMed]

38. Walters, C.; Engels, J. The effects of storing seeds under extremely dry conditions. Seed Sci. Res. 1998, 8, 3-8.

39. Rajjou, L.; Duval, M.; Gallardo, K.; Catusse, J.; Bally, J.; Job, C.; Job, D. Seed germination and vigor. Annu. Rev. Plant Biol 2012, 63, 507-533. [CrossRef] [PubMed]

40. Shaban, M. Biochemical aspects of protein changes in seed physiology and germination. Int. J. Adv. Biol. Biomed. Res. 2013, 8, 885-898.

41. Priestley, D.A. Seed Aging: Implications for Seed Storage and Persistence in the Soil; Comstock Associates: New York, NY, USA, 1986.

42. Ponquett, R.T.; Smith, M.T.; Ross, G. Lipid autoxidation and seed ageing: Putative relationships between seed longevity and lipid stability. Seed Sci. Res. 1992, 2, 51-54. [CrossRef]

43. Clauss, M.J.; Venable, D.L. Seed germination in desert annuals: An empirical test of adaptive bet hedging. Am. Nat. 2000, 155, 168-186. [CrossRef] [PubMed]

44. Venable, D.L. Bet hedging in a guild of desert annuals. Ecology 2007, 88, 1086-1090. [CrossRef]

45. Lee, C.H.; Nam, K.W. Characteristics of seed germination in Heteropappus arenarius Kitam. native to Korea as influenced by temperature. Korean J. Plant Res. 2009, 22, 116-122.

46. Song, J.H.; Jang, K.H.; Hur, S.D. Variation of seed and germination characteristics of natural populations of Abies koreana Wilson, a Korean endemic species. J. Korean Soc. For. Sci. 2010, 99, 849-854.

47. Datta, S.C.; Gutterman, Y.; Evenari, M. The influence of the origin of the mother plant on yield and germination of their caryopses in Aegilops ovata. Planta 1972, 105, 155164. [CrossRef]

48. Halloran, G.M.; Collins, W.J. Physiological predetermination of the order of hardseededness breakdown in subterranean clover (Trifolium subterraneum L.). Ann. Bot. 1974, 38, 1039-1044. [CrossRef]

49. Jacobsohn, R.; Globerson, D. Daucus carota (carrot) seed quality: I. Effects of seed size on germination, emergence and plant growth under subtropical conditions. II. The importance of the primary umbel in carrot-seed production. In Seed Production; Hebblethwaite, P.D., Ed.; Butterworths: London, UK; Boston, MA, USA, 1980; pp. 637-646. 